J urral PerddkanBaresacknSastra V dume12, Nomr 1, April 2012

\title{
FENOMENA POLISEMIK BAHASA ARAB DALAM AL-QURAN
}

\author{
Wagino Hamid Hamdani \\ PBS Universitas Pendidikan Indonesia \\ Korspondensi: Jln. D r. Setiabudhi 229 Bandung 40154 \\ Pos-el: hwagino@yahoo.com
}

\begin{abstract}
Abstrak
Fenomena Polisemik Bahasa Arab dalam al-Quran. Artikel ini mengkaji fenomena polisemik bahasa Arab dalam al-Quran. Cakupan kajiannya meliputi 10 bentuk polisemik yang berwazan: fa'iil, fi'aal, fa'aan/ fu'laan, fu'l, fa'alah, fu'uul tafa'la/ tafa'al, tafa'aluu, af'al dan fa'al. Dari hasil analisis diperoleh variasi makna morfologis bagi setiap bentuk polisemik, yaitu: (1) bentuk fa'iil mengandung 5 makna morfologis; (2) bentuk fi'aal mengandung 4 makna morfologis; (3) bentuk fa'laan, fu'laan dan fi'laan mengandung 4 makna morfologis; bentuk fu'l mengandung 4 makna morfologis; (5) bentuk fa'alah mengandung 5 makna morfologis; (6) benuk fu'uul mengandung 4 makna morfologis; (7) bentuk tafa'al 5 makna morfologis; (8) bentuk tafa'aluu mengandung 8 makna morfologis; (9) bentuk af'al mengandung 10 makna morfologis; dan bentuk fa'al mengandung 5 makna morfologis. Makna morfologis setiap bentuk kata dapat teridentifikasi melalui distribusi morfologis, sarana sintaktis, dan mkna leksilak.
\end{abstract}

Kata kunci: Fenomena polisemik, makna morfologis

\begin{abstract}
Phenomenon of Arabic Language Polysemy in the Quran. This paper that examined the phenomenon of Arabic polysemy in the Koran. Coverage of the study inclused 10 forms of polysemy: fa>iil, fi >aal, fa>laan/fu>laan/ fi'laan, fu'l, fa'alah, fu'uul tafa'la/ tafa'al, tafa'aluu, af $>$ al and fa'al. Obtained from the results of the analysis are morphological variations in meaning for every from of polysemy, namely: (1) the fa>iil from contains 5 morphological meanings, (2) the fi>aal form contains 4 morphological meanings, (3) forms offa>laan, fu>laan and fi>laan contains 4 morphological meaning; (4) the form of fu'l contains 4 morphological meanings, (5) the form of fa'alah contains 5 morphological meanings, (6) the form fu'uul contains 4 morphological meanings, (7) the form of tafa>al contains 5 morphological meanings, (8) the form of tafa>aluu contains 8 morphological meanings; (9) the form of af>al contains 10 forms morphological meanings, and the form of fa'al contains 5 morphological meanings. Morphological meanings of each form of words can be identified through the morphological distribution, syntatic means, and lexical meaning.

Keywords: polisemik phenomenon, meaning of morphologically
\end{abstract}

p-ISSN 1412-0712 | e-ISSN 2527-8312 